\title{
Рецензии
}

Пространственная Экономика

2014. № 4. C. $170-178$

УДК $330+332+339$

\section{CROSS-BORDER TRADE AND INTEGRATION BETWEEN RUSSIA AND CHINA: AN INTERDISCIPLINARY PERSPECTIVE (Review of the Book by N. Ryzhova "The Economic Integration of Border Regions")}

\section{K. Tochkov}

Tochkov, Kiril I. - Ph. D. in Economics, Associate Professor. Department of Economics, Texas Christian University. TCU Box 298510. Fort Worth, TX 76129. E-mail: k.tochkov@tcu.edu.

DOI: $10.14530 /$ se.2014.4.170-178

Russia's trade with China has been steadily increasing over the past decade. But in recent months the economic cooperation between the two countries experienced a sudden boost that involved high-level meetings, a long-term multi-billion dollar contracts to deliver Russian gas to China, a ten-fold rise in the yuan-ruble trade on the Moscow Exchange, and the revival of a plan to build a bridge across the Amur River linking the two countries. The regions in Russia's Far East located along the Chinese border are best placed to benefit from this intensification of cross-border ties. But are they really?

In her book, Ryzhova is highly skeptical about such prospects and draws a bleak picture of Russia's border regions where overly centralized decision making, bureaucratic rent-seeking, and informal hurdles impose trade barriers that impede economic integration with China. In fact, the author is so pessimistic that she does not see any sense in offering policy recommendations as is customary in economic studies. Restricting or eliminating informal networks that dominate cross-border trade is nearly impossible because the rent-seeking bureaucrats that design the relevant policies are themselves involved in these activities. In addition, decreasing the extent of centralization in economic decision making depends on politicians at the center who are not interested in ceding power to the regions. In the long run, Ryzhova sees no rational alternative to the full liberalization of cross-border ties

(C) Tochkov K., 2014 
between Russia and China that would lower trade barriers and stimulate economic integration. But this will most likely be a long and tortuous process.

These conclusions are the result of a detailed study on border regions and their role in cross-border economic integration. The main argument of the book is that this topic needs to be examined using an interdisciplinary approach that involves not only mainstream economics but also institutional economics, economic geography, and economic sociology. Accordingly, the author divides her book into three chapters, each of which is dedicated to a specific approach that offers distinctive insights into border regions. This is indeed a very fruitful exercise as each discipline and its corresponding methodology are subject to limitations that do not allow for the full picture to emerge. Each chapter begins with a review of the existing literature and an outlook on border regions and economic integration from the perspective of a given discipline. Next, the described approach is mostly applied to the study of the regions in Russia's Far East located along China's border. At the end of each chapter several appendices provide valuable information mostly in the form of descriptive statistics that support or complement the arguments made in the main body of the chapter.

The three approaches that have been adopted in the book to study border regions are very different and create certain challenges as they stem from particular academic disciplines, use specific terminology and methodology, and exhibit some irreconcilable differences. However, the author skillfully combines them and successfully creates a smooth transition between the chapters by ensuring that the disadvantages or weakness of one approach are addressed in the following chapter by another approach, which in turn is complemented by a third one. This is no small feat when one considers the many pitfalls of interdisciplinary work. The first chapter employs the mainstream economic view of borders which has been heavily influenced by the new economic geography. This approach emphasizes the application of statistical models that provide valuable empirical evidence on a number of issues. Most importantly, the statistical analysis allows for the measurement and quantification of certain processes and effects associated, for instance, with agglomeration and trade barriers along the border. However, despite the advantages of this empirical strategy, the models suffer from being overly simplistic because they place a strong emphasis on bilateral distance but do not account for various differences, such as the historical and industrial development of border regions. Furthermore, these models are constrained by the availability of data which precludes the analysis of institutional factors that are not easy to measure and for which data is not readily available.

Therefore, the second chapter focuses exactly on the role of institutions in cross-border trade and their effect on border regions. The theoretical framework is provided by institutional economics. Although this perspective is more descriptive, 
it offers major insights into the nature of cross-border exchange in border regions which is not recorded in the data and is thus not easily quantifiable. While the institutional approach illustrates the importance of formal and informal integration processes in border regions and highlights the tensions between the center and the periphery, it nevertheless is limited to the discussion of national or regional phenomena. Accordingly, it fails to explain the workings of an integrated market across the border at the micro level. This is where the third chapter steps in and employs economic sociology to study the interactions between Russian and Chinese businesses, individuals, middlemen, and bureaucrats. The methodology here focuses on one specific cross-border region (Blagoveshchensk and Heihe) and relies heavily on surveys and interviews but also on some region-specific data on cross-border exchanges.

The interdisciplinary approach is one of the key features and main strengths of the book as the subject of the integration of border regions is not limited to any specific field of study. Combining various disciplines to explain a phenomenon is often problematic because researchers are not well versed in both disciplines and have problems combining them to produce a unified picture. Ryzhova acknowledges the difficulties and does a great job of integrating these three approaches in her goal to analyze the economic integration across the Sino-Russian border. She also exhibits intimate knowledge of the theoretical foundations as well as the methodologies and practical applications of economic geography, institutional economics, and economic sociology. As a result, the book will be of interest not only to economists but to all social scientists who want to gain fascinating insights into border regions in general, and those in Russia's Far East in particular. Ryzhova's work would also serve as a good example of how to conduct interdisciplinary research that involves different approaches to conducting research in the social sciences.

The interdisciplinary perspective produces some very interesting results and highlights the difficulties of economic integration across borders. In the first chapter, the author focuses on three specific effects that are examined using regression analysis. The first one deals with localization and agglomeration. The main hypothesis is that once borders open, firms in Russia would choose to relocate to border regions in an attempt to minimize transportation costs and take advantage of the scale of foreign markets across the border. This, in turn, would have an effect on the specialization (and thus on the comparative advantage) of border regions. The analysis is conducted over a relatively brief period (2005-2010) due to data limitations but it covers a dozen sectors. The results indicate that, in general, the integration of Russian regions with China had a less significant effect on the regional specialization than the interaction with other foreign markets in Europe and CIS. The existence of cross-border infrastructure with China stimulated the specialization only in the areas of commerce and other non-ferrous metals. Furthermore, only the 
specialization in forestry benefited regions that are close to the Chinese border but the interaction with China was not the primary reason for this specialization. These findings suggest that the Sino-Russian border was less open than Russia's borders with Europe and CIS and therefore this led to a lack of agglomeration effects with the exception of a few sectors. But this might also be the result of not accounting for institutional and other factors that are discussed by the author in the second chapter.

The second effect addressed in the first chapter focuses on the cost of labor in the regions relative to the cost of labor in the center, which is taken to be Moscow. The hypothesis is that the cost of labor would be relatively higher in regions closer to the border in the case of an open economy where the forces of gravity would attract labor to the border regions. On the contrary, in a relatively closed economy where the centrifugal forces are stronger, labor would be rewarded more if it is located closer to the center. The results show that over the period 2002-2010 wages decreased the farther away a region was located from Moscow. This tendency strengthened over the sample period which suggests that the cross-border economic integration supposed to unleash the forces of gravity has not been successful. A more detailed analysis demonstrates that some sectors experienced higher relative wages in regions bordering China. These were again mostly concentrated in the timber industry, other non-ferrous metals, and, to a limited extent, in textiles.

The third effect explored in the first chapter analyzes increases in the cost incurred while transporting goods across the border. These so-called border effects are a broad measure of the trade barriers and can be used to assess the potential for crossborder economic integration. The main hypothesis is that in the case of economic integration, border effects will decline as trade barriers are gradually dismantled. While the traditional approach to estimating border effects involves trade flows as the dependent variable, Ryzhova opts for an alternative approach exploring instead the law of one price. The dependent variable in this case is the volatility of relative prices in Sino-Russian trade. The results for the period 2002-2007 indicate that the border effects increase the volatility in relative prices which means that borders impede trade flows. At the national level, the effect of borders is found to be more than five times stronger than the impact of distance. For border regions along the Chinese border, the border effects are 3 times larger than for distance, which suggests that these regions are slightly better integrated with China than Russia as a whole.

Overall, the findings in the first chapter already offer a bleak account of crossborder integration between China and Russia. Centrifugal forces are shown to be stronger than gravity towards regions bordering large foreign markets like the China. Border regions exhibit specialization in only a very small number of sectors associated with cross-border exchanges. Wages in these regions seem relatively lower than in areas closer to the center, and borders still appear to play a significant role in obstructing trade flows. 
The appendices to the first chapter provide additional analyses that largely support these conclusions but focus entirely on the regions in Russia's Far East that border China. The first appendix explores the specialization and the revealed comparative advantage of these regions and its change over the 2000s. The strong demand from China for primary products seems to have led to a rapid increase in the production of certain primary industries, such as forestry and aquaculture. In contrast, none of the border regions exhibits specialization or a comparative advantage in manufacturing. The second appendix focuses on the spatial distribution of Chinese FDI across Russian regions. The statistics suggest again that border regions in Russia's Far East are the main recipients of Chinese FDI in the primary sector. However, most of the FDI from China and other countries destined for the secondary and tertiary sectors is concentrated in other regions.

The third appendix gives a short overview of the population density in border regions at the county level in China and Russia. Three of the counties with the best cross-border infrastructure on the Russian side of the border exhibit an increase in population density which seems to be closely linked to the intensification of the cross-border economic cooperation with China. On the Chinese side of the border, only one county experienced a similar rise. The fourth appendix studies in more detail the factors that lead to high border effects in Sino-Russian trade, including tariff and non-tariff barriers. The interesting conclusion is that despite a large number of cooperation agreements, most of them remain at the stage of good intentions, while the actual trade flows are subject to political and geo-strategic constraints that often defy market logic. The last, fifth, appendix focuses on the spatial dimension of SinoRussian trade by customs area and shows that border regions on the Russian side were not the main benefactors. Instead, most of the trade concentrated in the regions in Western Russia, and Moscow and St. Petersburg in particular. On the Chinese side, manufacturing centers in the southern part of the country were also heavily involved in the trade with Russia, but border regions, and Heilongjiang province in particular, were the major benefactors, which contrasts with the situation in Russia.

The second chapter of the book explores institutional factors that play a role in cross-border trade and integration between China and Russia. Although these factors are important, they are not easily integrated in the empirical models of the economic geography approach mainly due to lack of appropriate data and measurements. The analysis focuses on two interrelated dichotomies. The first one deals with formal vs. informal institutions, and in particular with formal and informal cross-border exchanges. The informal institutions are further subdivided into extralegal and illegal, the former being not legal but also not criminal in nature. The second dichotomy refers to the role of the center in managing cross-border trade in border regions. The center can opt for an overly strong centralization by, for instance, sealing the border or gaining control over a large share of revenues from 
cross-border trade. Decentralization, on the other hand, would leave border regions complete freedom in managing and enjoying the benefits of free trade. Both of these extreme approaches would give a boost to informal cross-border trade. In the first case, this is because the centralization proves too restrictive, while in the second because the state is completely absent from its regulatory and other functions.

The chapter proceeds to analyze the nature of trade between Russia and China over the period from the 1980s to 2006. The silver lining in the analysis is provided by the two dichotomies of the extent of informal cross-border interactions and of the extent of the centralization of the decision-making and fiscal freedoms in border regions. In China, the author identifies three distinctive phases. The first one which lasted until 1991 was characterized by strong decentralization, allowing Chinese provinces to attract FDI and engage in international trade. This led to a rapid rise in informal cross-border trade. In 1992, the Chinese government established additional institutions that focused on border regions and cities and offered them special status and preferential treatment. Since 1996, the central government gradually reversed the decentralization process and abolished many of these measures. Accordingly, cross-border trade, and especially the informal channels of interaction, declined.

The author detects a very similar pattern for Russia. Already during the Soviet period of the late 1980s border regions benefited from some preferential institutions, which, however, were still considered only experimental. The new economic policies implemented in 1992-1993 suddenly opened all borders to free trade. The hope was that border regions would benefit from their advantageous locations. However, the lack of protection for domestic industries not used to foreign competition, the frequent change of laws and norms and the resulting uncertainty for businesses, as well as the lack of a national strategy for economic integration led to the emergence of rampant corruption and intensified informal cross-border trade. Since 1994, a gradual recentralization was implemented mainly with the goal of avoiding separatist tendencies in the regions and increasing the federal share of customs revenues. The Federal Customs Agency turned into a major tool for channeling the revenues from trade into the federal budget. As the dependence of the federal budget on revenues from trade increased, the willingness to implement new measures that would give border regions preferential treatment or more freedom in decision making declined. This, in turn, increased the border effects.

In summary, the second chapter again confirms the pessimistic view about the potential of cross-border integration between the regions along the Sino-Russian border. Due to restrictions on regional decision making, elimination of preferential treatment for border regions, and the centralization of revenues from trade, the process of economic integration in border regions was mostly dominated by informal, and extralegal, exchanges in particular. The appendices provide supporting evidence based on a statistical analysis of the data. The focus, however, is on using 
the data to show the extent of extralegal trade flows that are not recorded in the official statistics. The first appendix deals with the flow of goods and investigates the discrepancy of export and import figures from Chinese and Russian sources. This serves as an indicator for the size of informal trade. Indeed, the author shows that the indicator was high during the early 1990s but gradually decreased with the emergence of centralization tendencies. The next few appendices conduct a similar analysis with a focus on trade in services, capital and labor flows, and trade at level of border regions. Among them, the author conducts an interesting investigation of tourist flows between Russia and China, which also conceals part of the informal nature of cross-border trade as many tourists were actually participating in schemes to transport goods across the border without paying customs duties.

The third chapter of the book is fascinating because it deals with the actual extralegal arrangements of economic integration at the micro level in a border region. The author has chosen to focus on the area encompassing Blagoveshchensk in Amurskaya region and the Chinese town of Heihe in Heilongjiang province across the Amur River. The choice is justified by pointing out that these cities are a unique pair in that both are very close to the border and depend heavily on cross-border trade. In addition, the author lives and works in Blagoveshchensk and has conducted numerous interviews and surveys in the area, which are used in the chapter. The interviewees include representatives of the local and customs administration, business owners and farmers, workers, and middlemen, both Chinese and Russians. The chapter is dedicated to three interrelated topics. The first one deals with the various manifestations of extralegal cross-border exchanges. For the trade in goods, one of the most popular informal schemes has been to hire people to travel to China as tourists and then return carrying goods that can be resold at a premium on the Russian market. Additional strategies to avoid paying customs duties include declaring a value of the imported goods that is below the real one or importing goods that are declared officially as another category of goods. In the area of services, Chinese firms often provide services as subcontractors in Russia without having to declare officially their activities. The Russian partner company applies for permission to hire Chinese workers without mentioning that these are actually working for a single Chinese company that manages and supervises their activities. Furthermore, many Chinese workers enter Russia on tourist visas but actually seek employment. Capital inflows from China are also concealed from authorities by finding a straw man on the Russian side, while capital outflows make use of shadow banking services. All of these extralegal arrangements are used to circumvent the high border effects illustrated in previous chapters, and often involve paying bribes to local authorities.

The agents taking part in these schemes consist of traders, officials, suppliers, and smugglers. Ryzhova develops a detailed analysis of the interactions between 
these agents and of how their networks changed over time. For instance, in the early 1990s the main participant in informal cross-border trade was the trader. As trade becomes more sophisticated and more stable business networks develop across the border, suppliers join the arrangement. In the late 1990s, many of the Chinese suppliers move to Russia creating a new class of agents. Officials were involved from the start by seeking rents. But their power has gradually increased as more and more restrictions are imposed on extralegal cross-border activities. This is when smugglers emerge guarantying delivery of goods at reduced customs duties.

The last part of the third chapter examines cross-border activities in agriculture. In particular, the author shows how Chinese farmers and traders have gradually come to dominate and even monopolize agricultural imports into Blagoveshchensk. As the restrictions on cross-border trade rose over the past decade, many Chinese farmers have moved to Russia where they engage in agricultural activities. However, they use informal arrangements such as hiring a Russian straw man so as to avoid dealing with the local authorities that impose various hurdles to immigrants. In addition, Chinese traders control the wholesale distribution of the produce grown by Chinese farmers in Russia or imported by Chinese firms, which gives them the power to set prices on the local market in Blagoveshchensk.

The third chapter delivers further proof from a different perspective that concurs with the findings of the first two chapters. The trade barriers along the Sino-Russian border are high and have been increasing over the past decade. At the micro level, this resulted in the emergence of various extralegal schemes and institutions that attempt to lower the adverse effects of the border. Although these activities promote economic integration of border regions to a certain degree, they also contribute to market distortions that breed corruption, encourage tax dodging behavior, decrease competition among firms, and create monopolies and protected firms that have advantages over other market participants.

The recent intensification of Sino-Russian economic cooperation has gained a lot of attention and the book by Ryzhkova could not have come at a better moment. However, those who seek in this book confirmation for the enthusiastic reports about the future of economic ties between the two emerging economies will be disappointed. The author concludes that the prospects for deeper economic integration, especially between the border regions in Russia's Far East and China's Northeast, are grim. This finding is not new as previous research has identified similar problems serving as deterrents to cross-border trade and capital flows in the region $[1 ; 2]$. But the interdisciplinary approach, the breadth of topics, and the depth of the analysis in Ryzhkova's book turn it into a unique and seminal work that will not be surpassed anytime soon. 


\section{REFERENCES}

1. Glazyrina I., Faleichik A., Faleichik L. Cross-Border Cooperation in the Light of Investment Processes: More Minuses Than Pluses so Far. Problems of Economic Transition, 2012, no. 55 (6), pp. 43-62.

2. Thornton J., Ziegler C. Russia's Far East: Region at Risk. Seattle: University of Washington Press, 2002, 484 p.

\section{ПРИГРАНИЧНАЯ ТОРГОВЛЯ И ИНТЕГРАЦИЯ МЕЖЛУ РОССИЕЙ И КИТАЕМ: МЕЖДИСЦИПЛИНАРНАЯ ПЕРСПЕКТИВА (рецензия на книгу Н. Рыжовой «Экономическая интеграция приграничных регионов»)}

К.И. Тошков

Тошков Кирил И. - доктор экономики, адъюнкт-профессор, Ph. D. in Economics. Экономический департамент Техасского Христианского университета. Форт Уорс, Техас, США. E-mail: k.tochkov@tcu.edu.

ЛИТЕРАТУРА

1. Glazyrina I., Faleichik A., Faleichik L. Cross-Border Cooperation in the Light of Investment Processes: More Minuses Than Pluses so Far // Problems of Economic Transition. 2012. No. 55 (6). Pp. 43-62.

2. Thornton J., Ziegler C. Russia's Far East: Region at Risk. Seattle: University of Washington Press, 2002. 484 p. 